Wiraraja Medika : Jurnal Kesehatan
https://www.ejournalwiraraja.com/index.php/FIK
2088-415x (Print) |2685-9998 (online)

\title{
Pengaruh Konsumsi Sari Buah Jambu Merah dan Madu terhadap Kenaikan Nilai HB pada Ibu Hamil di Tempat Praktek Mandiri Bidan Muarofah Surabaya
}

\author{
Ratna Indriyani ${ }^{1}$, Aulia $^{2}$, Maulana Widi Andrian ${ }^{3}$, Emdat Suprayitno ${ }^{4}$ \\ 1,2,3,Program Studi Sarjana Kebidanan, Universitas Wiraraja Madura \\ ${ }^{4}$ Program Studi profesi Ners, Universitas Wiraraja Madura \\ 1ratnaindriyani@wiraraja.ac.id*,2aulia.fik@wiraraja.ac.id,'maulana.widi.fik@wiraraja.ac.id, \\ ${ }^{4}$ emdat@wiraraja.ac.id \\ *Corresponding author
}

INFORMASI ARTIKEL

Revised: 21-04-2020

Accepted: 23-05-2020

Kata kunci:

Anemia, HB, Ibu hamil

\section{ABSTRAK}

Kehamilan merupakan suatu hal yang fisiologis tetapi, dalam kehamilan tidak sedikit ibuhamil yang mengalami masalah seperti anemia. Tujuan penelitian ini adalah untuk mengetahui pengaruh pemberian jus jambu biji merah dan madu terhadap peningkatan kadar HB pada ibu hamil Trimester II dan III dengan Anemia ringan. Penelitian ini merupakan penelitian quasy eksperimental dengan rancanngbangun non equivalent control group pre test dan post test design. Sampel dalam penelitian ini ibuhamil trimester II dan III sebanyak 32 orang yang dibagi menjadi dua kelompok yaitu 16 responden kelompok perlakuan dan 16 responden kelompok kontrol. Teknik pengambilan sampel menggunakan accidental sampling. Pengumpulan data menggunakan lembar observasi. Analisa data menggunakan uji wilcoxon. Hasil penelitian menunjukkan bahwa Kadar $\mathrm{Hb}$ ibu hamil sebelum diberikan sari buah psidum guajava dan madu semuanya dengan nilai Hb rata-rata 9.81 .Kadar $\mathrm{Hb}$ ibu hamil sesudah mengkonsumsi sari buah psidium guajava dan madu sebagian besar nilai $\mathrm{Hb}$ ibu hamil meningkat pada kelompok perlakuan yaitu nilai $\mathrm{Hb}$ rata-rata 10,25 sedangkan pada kelompok control tidak terdapat perbedaan nilai $\mathrm{Hb}$ sebelum dan sesudah perlakuan rata-rata yaitu 9,81 . Hasil analisis uji wilcoxon $\mathrm{p}=0,000(\mathrm{p}<0,05)$. Kesimpulan penelitian ini yaitu Ada pengaruh yang signifikan pemberian sari buah psidium guajava dan madu terhadap peningkatan kadar Hb ibu hamil. Diharapkan bagi ibu hamil untuk rutin melakukan pemeriksaan kadar $\mathrm{Hb}$ untuk mengetahui lebih dini adanya anemia dalam kehamilan sehingga dapat dilakukan tindakan preventif

\section{ABSTARCT}

Keyword:

Anemia, Hb, pregnant mother
Pregnancy is one of the Physiology things but, in the process of pregnancy not a little pregnant mothers that experienced the problem like Anemia disease. The Aim of the research is To Known the effect in giving the red Guava juice and honey into the e knhancement $H B$ level for the Pregnant Women in semester two and semester Three by the Light anemia. The method employed in this research was Experimental Quasy by Up Design Non equivalent Control Group pre test and post test design . the instrument or the sample of this research is the pregnant mothers in semester two and semester three consists of 32 as informants and they are will divide into the two groups as follows: 16 Respondent in treatment groups and 16 respondent in control groups. The technique that used in this research was accidental sampling. The data was collected by using observation task. The data will analyse by using Wilcoxon test. The result of the research that the level of Pregnant mother's HB before Giving the Red Guava Juice and honey is in the average level of 9,81. The HB level of pregnant mother's after Giving the Red Guava Juice and honey most of the levels of Pregnant Mother's HB was increased in the treatment group in the average level of 10,25 gr \%, while in the control group have no found the differentiated of the $\mathrm{HB}$ level before and after the treatment in average level of $9,81 \mathrm{gr} \%$ by the result of the Wilcoxon test analyse $p=0,000(p<0,05)$. Based on the previous analysis above writer would like to draw some conclusion as follows: the sicnificant influence in giving the Red Guava Juice and honey to 
increase the HB levels of pregnan mother's. its expected all the pregnant women to Check up routine about the HB level to knowing early the Anemia's effect in Pregnancy so that it cawill be taken by the Preventive treatment

\section{Pendahuluan}

Jumlah Kematian Ibu (AKI) sebanyak 359/100.000 Kh, Angka ini masih di bawah dari target SDGs. Penyebab kematian ibu tertinggi adalah perdarahan dan salah satu penyebab dari perdarahan adalah anemia. (Pusdatin, 2017). Besarnya prevalensi anemia dalam kehamilan dampaknya juga besar. Sebesar 55\% banyaknya kejadian anemia dalam kehamilan secara global. Kondisi dengan kadar $\mathrm{Hb} 11$ gr\% prevalensinya sekitar 20$89 \%$, hal ini diungkapkan oleh WHO. Hasil penelitian di Malaysia bahwa sebanyak 20 $\%$ ibu yang kadar Hbnya di bawah 6,5 gr/dl melahirkan bayi secara premature. (Almabruroh \& Alfi, 2016). Penyebab kematian ibu terbesar adalah perdarahan sebanyak 28\% dan infeksi. Hal ini disebabkan oleh ibu yang anemia dan kekurangan energy kronis (KEK). Anemia dalam kehamilan seringterjadi di Negara berkembang dan merupakan sebuah masalah terbesar yang harus segera diatasi. Kematian ibu yang disebabkan oleh anemia dalam kehamilan berkisar 40\% yang terjadi dinegara berkembang.(Aminin, Wulandari, \& Lestari, 2016)

Keadaan ibu hamil dengan nilai hemoglobin di bawah 11 gr\% pada trimester I dan III atau kadar < 10,5 gr\% pada trimester IIdisebut anemia dalam kehamilan. Hal ini berbeda dengan keadaan pada perempuan normal dikarenakan pada wanita hamil terjadi hemodilusi, hemodulis imeningkat di kehamilan trimester II. Karena meningkatnya kebutuhan zat makanan dan terjadi perubahan didalam darah dan sumsum tulang sehingga menyebabkan terjadinya anemia dalam kehamilan. Wanita hamil juga rentan terjadi hidremia atau hipervolomia, akibatnya eritrosit berkurang di bandingkan dengan bertambahnya plasma dengan demikian terjadi trombositopenia. (Fitriani, Panggayuh, \& Tarsikah, 2018).(Munafiah, Kusyati, \& Inayati, 2019)

Untuk mengatasai anemia dapat dilakukan pencegahan dan penanganan yaitu dengan meminum tablet tambah darah (Fe) yang sudah dianjurkan oleh tenaga kesehatan. Selain itu tingkatkan konsumsi hidangan yang mengandung zat besi baik dari sumber makanan hewani maupun dari sumber makanan nabati.
Vitamin C (asam askorbat) berkontribusi besar proses absorpsi zat besi. Vitamin $C$ dapat diperoleh dari tablet suplemen vitamin $C$ maupun dari buah-buahan dan sayuran. Buah yang kaya vitamin $C$ adalah jambu biji merah. Penyerapan zat besi nabati dapat meningkat empat kali dengan mengkonsumsi vitamin C sebanyak $200 \mathrm{mg}$ dan juga dapat membantu penyerapan obat sekitar 30\%. Kandungan vitamin C $87 \mathrm{mg} /$ gram lebih besar dua kali lipat dibandingkan dengan kandungan vitamin $C$ yang terdapat di jeruk. Didalam 100 gram Psidium guajava berisi 49 kalori, Protein 0,9 gram, Lemak 0,3 gram, Karbohidrat 12,2 gram, Kalsium $14 \mathrm{mg}$, Fosfor $28 \mathrm{mg}$, Besi 1,1 mg, Vitamin A 25 SI, Vitamin B1 $0,05 \mathrm{mg}$ dan Air 86 gram. Besarnya kandungan vitamin $\mathrm{C}$ di dalam Psidium guajava sangatlah bermanfaat untuk penyerapan zat besi didalam tubuh sehingga dapat meningkatkan hemoglobin. (Prasetyanti \& Putri, 2017)

Kandungan zat besi di dalam madu merupakan mikromineral yang sangat penting di dalam tubuh. Selain itu kandungan lain madu yang berperan penting dalam melarutkan zat besi yaitu vitamin C. Madu juga mengandung beberapa multi mineral yang meliputi : belerang (S), kalsium (Ca), tembaga $(\mathrm{Cu})$, mangan $(\mathrm{Mn})$, besi $(\mathrm{Fe})$, fosfor $(\mathrm{P})$, klor $(\mathrm{Cl})$, kalium (K), magnesium (Mg), iodium (I), seng (Zn), silikon (Si), natrium $(\mathrm{Na})$, molibdenum (Mo) dan aluminium (Al) sedangkan potasium merupakan mineral utama pada madu, Selain itu madu mengandung multivitamin yang meliputi vitamin $\mathrm{E}$, vitamin $\mathrm{C}$ serta vitamin $\mathrm{B} 1, \mathrm{~B} 6$, dan asam folat.(Isnainy, Arianti, \& Rosalia, 2020). Tujuan penelitian ini adalah untuk mengetahui adanya pengaruh dari konsumsi sari buah psidium guajava dan madu terhadap peningkatan nilai $\mathrm{Hb}$ wanita hamil trimester dua dan tiga dengan anemia ringan.

\section{METODE PENELITIAN}

Riset ini dengan metode Quasi Eksperimen dan rancangan penelitian "non equivalent control group pre test dan post testdesign “.(Carsel, 2018). Populasi penelitian ini yaitu wanita hamil trimester II yang berjumlah 50 orang dan wanita hamil trimester III berjumlah 75 orang. Sampel 
penelitian ini berjumlah 16 orang dengan kriteria wanita hamil trimester II dan III yang mengalami anemia ringan dan yang mengkonsumsi zat besi.

\section{HASIL PENELITIAN}

1. Distribusi frekuensi sampel berdasarkan nilai $\mathrm{Hb}$ pada kelompok kontrol di PMB Muarofah, Amd.keb

\begin{tabular}{lrrrr}
\hline Kategori & Mean & Median & $\begin{array}{c}\min - \\
\max \end{array}$ & $\mathbf{P}$ \\
\hline Pre test & 9.81 & 10 & $9-10$ & 0,655 \\
\hline Post test & 9,81 & 10 & $9-10$ & \\
\hline $\begin{array}{l}\text { Berdasarkan tabel diatas } \\
\text { nilai Hb }\end{array}$ & mada ibu henuknan hamil rata-rata & 9,81 \\
sebelum di intervensi maupun sesudah \\
di intervensi tidak terdapat perbedaan.
\end{tabular}

2. Distribusi Frekuensi Sampel Berdasarkan Nilai $\mathrm{Hb}$ Ibu kelompok perlakuan.

\begin{tabular}{lcccc}
\hline Kategori & Mean & $\begin{array}{c}\text { Med } \\
\text { ian }\end{array}$ & $\begin{array}{c}\text { min- } \\
\max \end{array}$ & $\mathbf{P}$ \\
\cline { 1 - 4 } Pre test & 9,81 & 10 & $9-10$ & \\
\cline { 1 - 4 } $\begin{array}{l}\text { Post } \\
\text { test }\end{array}$ & 10,2 & 10 & $10-11$ & 0,00 \\
\hline \multicolumn{2}{r}{ Berdasarkan } & \multicolumn{2}{c}{ tabel } & diatas
\end{tabular}

menunjukkan bahwa rata-rata nilai $\mathrm{Hb}$ pada wanita hamil sebelum perlakuan dan sesudah perlakuan terdapat perbedaan yaitu nilai $\mathrm{Hb}$ perlakuan lebih besar dari sebelum perlakuan.

3. Distribusi Frekuensi Sampel Berdasarkan dampak konsumsi sari buah Psidium guajava dan madu terhadap nilai $\mathrm{Hb}$ ibu hamil di PMB Muarofah, Amd.Keb Surabaya

a. Tabel $\mathrm{Hb}$ sebelum intervensi

\begin{tabular}{cccc}
\hline No & Nilai Hb & $\begin{array}{c}\text { Tidak } \\
\text { Meningkat }\end{array}$ & Persentase \\
\hline $\mathbf{1}$ & Meningkat & 3 & $18,75 \%$ \\
\hline $\mathbf{2}$ & $\begin{array}{c}\text { Tidak } \\
\text { Meningkat }\end{array}$ & 13 & $81,25 \%$ \\
\hline & Total & 16 & $100 \%$ \\
\hline
\end{tabular}

b. Tabel $\mathrm{Hb}$ sesudah perlakuan

\begin{tabular}{cccc}
\hline No & Nilai Hb & $\begin{array}{c}\text { Tidak } \\
\text { Meningkat }\end{array}$ & Persentase \\
\hline $\mathbf{1}$ & Meningkat & 15 & $93,75 \%$ \\
\hline $\mathbf{2}$ & $\begin{array}{c}\text { Tidak } \\
\text { Meningkat }\end{array}$ & 1 & $6,25 \%$ \\
\hline & Total & 16 & $100 \%$ \\
\hline
\end{tabular}

Berdasarkan tabel diatas menunjukkan bahwa setelah diberikan sari buah psium guajava dan madu pada kelompok perlakuan sebagian besar nilai $\mathrm{Hb}$ meningkat yaitu sebanyak 15 sampel $(93,75 \%)$ dan nilai $\mathrm{Hb}$ tetap sebanyak 1 sampel (6,25\%). Sedangkan pada kelompok kontrol sebagian besar nilai $\mathrm{Hb}$ tidak meningkat sebanyak 13 sampel $(81,25 \%)$ dan nilai $\mathrm{Hb}$ yang meningkat sebanyak 3 sampel $(18,75 \%)$.

\section{PEMBAHASAN}

\section{A. Kadar Hb Wanita Hamil Sebelum Konsumsi Sari Buah Psidium Guajava dan Madu}

Hasil penelitian sebelum diberikan sari buah psidium guajava dan madu menunjukkan bahwa semua sampel mengalami anemia ringan. Dengan anemia rata-rata pada kelompok perlakuan dan kelompok control yaitu 9,81 gr\%. Anemia yang terjadi pada kehamilan seringkali disebabkan oleh defisisensi besi. Defisiensi besi tersebut disebabkan adanya kebutuhan nutrisi yang banyak pada saat kehamilan. Dimana juga dalam kehamilan terjadi proses pengenceran darah sebagai akibat dari hidremia cardiac output yang meningkat. (Fitriani, 2018)

Faktor lain yang menyebabkan anemia ringan yang didapa pada saat observasi antara lain nutrisi yang kurang,tingkat pendidikan ibu,dan sosial ekonomi, ibu hamil kurang istrahat dikarenakan bekerja.(Ningtyastuti, 2018)

\section{B. Kadar Hb Wanita Hamil Sesudah Konsumsi Sari Buah Psidium Guajava dan Madu \\ Berdasarkan hasil penelitian} menunjukkan bahwa setelah diberikan sari buah psidium guajava dan madu pada kelompok perlakuan sebagian besar nilai $\mathrm{Hb}$ meningkat rata-rata 10,25 gr\%. Sedangkan pada kelompok kontrol tidak terdapat perbedaan sebelum dan setelah diberikan perlakuan yaitu hb rata-rata 9,81gr\%. Peningkatan nilai $\mathrm{Hb}$ setelah diberikan intervensi karena didalam Psidium guajava mengandung zatbesi sebesar 1,1mg,dimana zat gizi 1,1 mg tersebut berperan dalam pembentukan sel darah merah. Fungsi vitamin $\mathrm{C}$ yang terkandung dalam jambu biji merah adalah menyusutkan besi feri (Fe3+) menjadi ferro (Fe2+) di dalam usus halus sehingga mudah diabsorpsi.(Isnainy, 2020). Madu adalah makanan yang berpotensi sebagai basa. 
Unsur yang bersifat basa meliputi kalium, natrium, kalsium, magnesium. Manfaat dari madu yang begitu besar yaitu mampu membasakan suasana lambung dan kandungan monosakarida yang sangat mudah dan cepat diserap oleh tubuh. Maka jika madu dikonsumsi oleh ibu hamil yang mengalami anemia ringan dapat meringankan keluhan selama kehamilan karena peningkatan hormon yang menurunkan mortilitas traktus digestivus, sehingga pengosongan lambung yang lama turut merangsang peningkatan sekresi $\mathrm{HCl}$, rangsangan mual dapat diantisipasi jika tubuh dapat mengkompesasi metabolisme glikogen di hati yang terjadi saat pagi hari dengan konsumsi madu sebelum bangkit dari tempat tidur. (Islamiyah, 2017; Saidah, 2018)

\section{Dampak pemberian sari buah Psidium guajava dan madu terhadap nilai Hb wanita hamil \\ Berdasarkan hasil analisis data} menggunakan uji wilcoxon didapatkan hasil pada kelompok perlakuan nilai $\mathrm{p}=0,000 \quad(\mathrm{P}<0,05) \quad$ dan pada kelompok kontrol nilai $\mathrm{P}=0,655(\mathrm{P}>0,05)$,yang artinya terdapat perbedaan nilai perbandingan pre test dan post test pada kelompok perlakuan dan kontrol. sedangkan perbandingan antara kelompok perlakuan dan kontrol menggunakan uji chi square di dapatkan hasil $\mathrm{p}=0,000(\mathrm{p}<0,05)$ yang artinya terdapat pengaruh yang pemberian sari buah psidium guajava dan madu terhadap peningkatan nilai $\mathrm{Hb}$ wanita hamil yang mengalami anemia ringan. Sari buah psidium guajava dapat meningkatkan nilai $\mathrm{Hb}$ dikarenakan didalam jambu biji merah banyak mengandung asam askorbat (Vitamin C). (Prasetyanti, 2017 ). Dimana vitamin $C$ berfungsi menyusutkan besi feri (Fe3+) menjadi ferro (Fe2+) di dalam usus halus sehingga mudah diabsorpsi, maka dengan tingginya kandungan vitamin $\mathrm{C}$ pada sari buah psdium guajava sehingga mempercepat proses menyusutkan feri menjadi ferro.(Isnainy, 2020). Karena kemampuan dapat meminimalkan rasa mual yang dialami oleh ibu hamil, hal ini sangat bermafaat bagi ibu hamil yang tidak suka meminum tablet fe dikarenakan efek samping dari table fe itu. (SAFITRI, 2019). Hal ini sejalan dengan penelitian dari Safitri tentang terapi jus bayam-jeruk sunkismadu terhadap kadar $\mathrm{Hb}$ pada ibu hamil.

\section{Kesimpulan dan Saran}

Kesimpulan dari riset ini adalah terdapat pengaruh dari meminum sari buah psidium guajava dan madu terhadap nilai $\mathrm{Hb}$ pada wanita hamil yang mengalami anemia ringan pada kehamilan trimester II dan III. Dimana dari 16 sampel wanita hamil, 13 dari sampel tersebut mengalami peningkatan nilai $\mathrm{Hb}$ setelah meminum sari buah psdium guajava. Perlunya penelitian lanjutan dengan penambahan variabel maupun pada sampel yang berbeda untuk lebih mengetahui keefektifan dan manfaat dalam upaya preventif anemia pada kehamilan.

\section{DAFTAR PUSTAKA}

Almabruroh, Z. C., \& Alfi, Y. (2016). Hubungan Antara Anemia pada Ibu Hamil dengan Kejadian Partus Prematur di RSUD Brebes tahun 2013. Siklus: Journal Research Midwifery Politeknik Tegal, 5(2).

Aminin, F., Wulandari, A., \& Lestari, R. P. (2016). Pengaruh kekurangan energi kronis (KEK) dengan kejadian anemia pada ibu hamil. Jurnal kesehatan, 5(2).

Carsel, S. H. (2018). Metodologi Kesehatan dan Pendidikan. Yogyakarta :Media Pustaka.

Fitriani, Y., Panggayuh, A., \& Tarsikah, T. (2018). Pengaruh pemberian jus jambu biji terhadap kadar hb pada ibu hamil trimester iii di polindes krebet kecamatan bululawang kabupaten malang. Jurnal EDUMidwifery, 1(2), 79-86.

Islamiyah, N. (2017). Pengaruh Madu Terhadap Kadar Hemoglobin Remaja Putri Kelas $X$ Yang Mengalami Anemia di SMKN 01 Mempawah Hilir. Jurnal ProNers, 3(1).

Isnainy, U. C. A. S., Arianti, L., \& Rosalia, D. (2020). PENGARUH KONSUMSI EKSTRAK DAUN KELOR DAN MADU TERHADAP PENINGKATAN HB IBU HAMIL DI WILAYAH KERJA PUSKESMAS WAY HALIM KOTA BANDAR LAMPUNG. Malahayati Nursing Journal, 2(1), 57-67.

Munafiah, D., Kusyati, E., \& Inayati, N. (2019). Pemberian Tablet Fe dan MAMA (Madu Kurma) Meningkatkan Kadar Hemoglobin 
Kehamilan Aterm dalam Persiapan Persalinan. Paper presented at the

Prosiding Seminar Nasional Unimus.

Prasetyanti, D. K., \& Putri, L. E. A. A. (2017). Efektivitas Jus jambu biji terhadap perubahan kadar $\mathrm{Hb}$ Pada ibu hamil trimester III di wilayah kerja puskesmas Bacem Kabupaten Blitar Tahun 2015. Strada Jurnal Ilmiah Kesehatan, 6(1), 9-13.

Pusdatin. (2017). Kementerian Kesehatan Republik Indonesia.

Saidah, H. (2018). KOMBINASI PEMBERIAN JUS JAMBU BIJI MERAH DAN MADU TERHADAP PENINGKATAN KADAR HB PADA IBU HAMIL. Jurnal Asuhan Ibu dan Anak, 3(1), 19-28. 